\title{
2山型スペクトルを考慮した港内静穏度解析の試みとその影響評価
}

\section{Evaluation of Harbor Tranquility with Considering Effect of Double-peaked Offshore Spectrum}

\author{
平山克也 $^{1} \cdot$ 加島寛章 $^{2} \cdot$ 仲井圭二 $^{3} \cdot$ 久高将信 $^{4}$ \\ Katsuya HIRAYAMA, Hiroaki KASHIMA, Keiji NAKAI and Masanobu KUDAKA
}

\begin{abstract}
Generally, a joint distribution of significant wave height, period and direction outside a harbor is analyzed with assumption that a single-peaked spectrum is observed in each time. However, the significant wave periods should be underestimated when double-peaked spectra are observed, and that seems to affect wave height exceedance within the harbor. In this paper, the occurrence frequency of the double-peaked spectrum is estimated by using newly proposed method. Moreover, the estimation of the probability of wave height exceedance within the harbor is carried out with considering both the separated significant periods of wind wave and swell from the double-peaked spectrum. On a berth in the target harbor, it reduces $0.1 \%$ when the number of underestimation of significant wave periods is $2 \%$ in whole observed spectra.
\end{abstract}

\section{1.はじめに}

港内静穏度解析に用いる沖波出現頻度分布は，各時刻 に観測された波形記録から得られる代表波の諸元（波高， 周期，波向き）をもとに，整理・作成されている。この 場合，ある時刻に観測される波浪が風波とうねりを同時 に含み，2山型スペクトルを成していると，この代表波 の諸元は, 結果的にこれらを合成したものになっている と考えられる。一方, 標準解析法に基づく港内静穏度解 析では，周期による荷役限界波高の違いを考慮している. したがって，2 山型スペクトルの発生頻度が少なくない 場合には，このうち周期の長い成分波の影響が荷役稼働 率算定時に過小評価されている恐れがある。また，これ は, 港内の海底地形が複雑で浅い場合ほど顕著になりや すい.

そこで本研究では, 急峻な海底地形を介して東京湾口 に面する久里浜港を対象とした港内静穏度解析を行い, 外洋からのうねりと湾内発生波から成る 2 山型スペクト ルの発生頻度を考慮した影響について, 従来の沖波出現 頻度分布を用いて算定した荷役稼働率と比較することに より明らかにする。なお，港内外の波浪変形計算のうち， 周期 $6 \mathrm{~s}$ 未満の入射波に対しては，港内の相対水深が一定 とみなせるとして高山法を，6s以上の入射波に対しては， 港内の水深変化に伴う波浪変形を算定できるようブシネ スクモデルをそれぞれ用い，荷役稼働率を算定する港内 の各岸壁前面の波高比を算定した。特に，ブシネスクモ デルによる波浪変形計算では代表波高を 2 種類設定し,

\footnotetext{
1 正会員 博 (工) (独) 港湾空港技術研究所海洋 - 水工部

2 正会員 工修 (独) 港湾空港技術研究所海洋 - 水工部

3 正会員理修 （株）エコー, 防災・水工部, 部長

4 正会員
}

平山（2008）の方法にならい，港外波高による港内波高 比の違いを考慮した荷役稼働率を算定した。

\section{2 山型スペクトルの抽出}

久里浜湾口に位置するアシカ島で2003〜2007年に取 得されたNOWPHAS 波浪観測データをスペクトル解析 し，式（1）に示す，高周波成分の影響を受けにくいス ペクトル有義波周期 $T_{\mathrm{m}-1,0}$ を算出した（合田，2008）.

$$
T_{m-1,0}=m_{-1} / m_{0} \quad m_{i}=\int_{0}^{\infty} f^{i} S(f) d f \quad(i=0,-1)
$$

ただし，ここでは特に風波・うねりを対象としたので, 式（1）を若干修正し， $0.033 \mathrm{~Hz}$ 以上（30s未満）の波工 ネルギーに対するスペクトル周期を式（1）'により算出 した.

$$
T_{m-1,0}=m_{-1} / m_{0} \quad m_{i}=\int_{f_{\min }}^{\infty} f^{i} S(f) d f \quad(i=0,-1) \quad \cdots \cdots(1),
$$

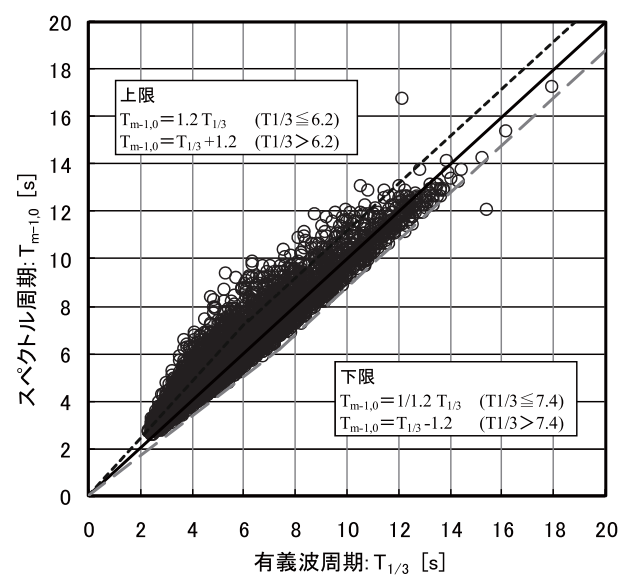

図-1 有義波周期とスペクトル周期との関係 


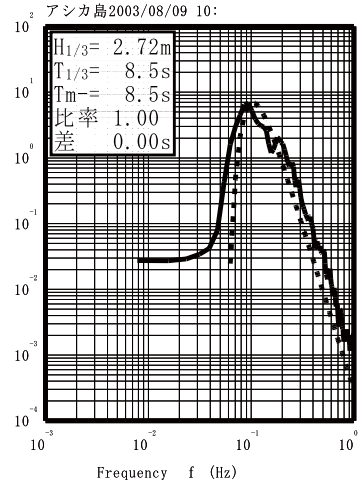

(a) 1 山型スペクトル

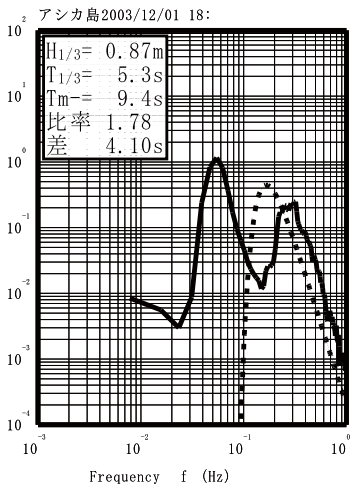

(b) 2 山型スペクトル
図-2 アシカ島観測データのスペクトル解析結果の例

ここで $f_{\min }=0.033$ とした. 一方, ゼロアップクロス法で 算定される有義波周期 $T_{1 / 3}$ とこれらを比較し, 図-1を得 た. 図中の破線は両者のばらつき範囲のうち下限を示し, 上限を示す点線はこれを対称に折り返したものである.

これらの範囲にあるプロットが計算された時刻では 1 山型スペクトルが出現しているのに対し (図-2 (a)), こ の範囲から外れたほぼすべてのプロットでは， $T_{1 / 3} \leq 6.2 \mathrm{~s}$ のとき $T_{m-1,0}>1.2 T_{1 / 3}, \quad T_{1 / 3}>6.2 \mathrm{~s}$ のき $T_{m-1,0}>T_{1 / 3}+1.2 \mathrm{~s}$ が 成り立ち，このとき顕著な 2 山型スペクトルが出現して いる (図-2 (b))。 そこで，この点線を境界線とし，これ より左上方にあるプロットを 2 山型スペクトルとして抽 出することとした。なお，図-2中の実線は観測スペクト ル, 破線は有義波諸元 $H_{1 / 3}, T_{1 / 3}$ に対する修正ブレットシ ユナイダー型スペクトルである。この結果，アシカ島で 5 年間に観測された波スペクトルのうち, 本研究で定義 した方法により抽出された，2山型スペクトルが観測さ れた時刻（1969デー夕）は，有意な水位変動が観測され た全時刻（19073デー夕）のうち10.3\%であった。ここ で，有意な水位変動とは，対象期間に観測された全 21912 データのうち, 久測時および静穏時を除いたデー タである。

\section{2 山型スペクトルを考慮した港内静穏度解析}

\section{（1）沖波出現頻度分布の再整理}

上記の方法により分類した 1 山型および 2 山型スペク トルに対する代表波浪諸元は，図-3に示す整理手順に従 い，次のように算定した。すなわち，あるしきい值を設 けて 2 山型スペクトルを高周波成分と低周波成分に分離 し，それぞれの波エネルギーに対応する有義波高，有義 波周期を算定した。アシカ島データの場合，このしきい 值は $0.15 \mathrm{~Hz}$ とした。これは, 解析された多くの 2 山型入 ペクトルの形状を実際に確認して設定したものである が，図-1で定義した範囲の上限掞よび下限を示す点線に
おいて，それぞれの変曲点を結ぶ線分と対角線の交点が 示す周期 $6.8 \mathrm{~s}(0.147 \mathrm{~Hz})$ にほぼ対応している.

このようにして分離したそれぞれの波浪成分は，一般 的な定義とは異なるが，本研究では便宜上， $0.15 \mathrm{~Hz}$ 以上 (周期 $6.7 \mathrm{~s}$ 未満) を風波成分， $0.15 \mathrm{~Hz}$ 未満（周期 $6.7 \mathrm{~s}$ 以上） をうねり成分と呼ぶことにする。したがって，1山型ス ペクトルに対しても，その有義波周期が $6.7 \mathrm{~s}$ 未満の場合 には風波，6.7s以上の場合にはうねりと呼ぶ.

また，2山型スペクトルを分離して得たそれぞれの波 浪成分に対する有義波相当波高抢よびスペクトル周期 は, 本研究での定義に従い境界周波数 $f_{\mathrm{lmt}}=0.15 \mathrm{~Hz}$ として, 次式により算定した。

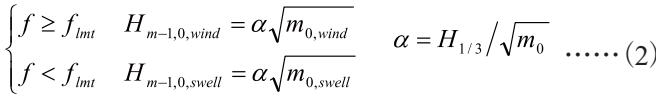

$$
\begin{aligned}
& \begin{cases}f \geq f_{l m t} & T_{m-1,0, \text { wind }}=m_{-1, \text { wind }} / m_{0, \text { wind }} \\
f<f\end{cases}
\end{aligned}
$$

ここで,

$$
\begin{cases}m_{i, \text { wind }}=\int_{f_{\text {litr }}}^{\infty} f^{i} S(f) d f & (i=0,-1) \\ m_{i, \text { swell }}=\int_{f_{\text {min }}}^{f_{\text {mint }}} f^{i} S(f) d f & (i=0,-1)\end{cases}
$$

ここに, $H_{1 / 3}$ は2 山型スペクトルが観測された時刻の水 位変動データに対して, ゼロクロス解析を行い得られた 有義波高, $H_{\mathrm{m}-1,0, \text { wind }}, T_{\mathrm{m}-1,0, \text { wind }}$, および $H_{\mathrm{m}-1,0, \text { swell }}$, $T_{\mathrm{m}-1,0, \text { swell }}$ はそれぞれ，風波成分，うねり成分に対する有 義波相当波高拉よびスペクトル周期である.

次に，波向き観測が害施されていないアシカ島におけ る各時刻の代表波向きは, 次のようにして設定した。す

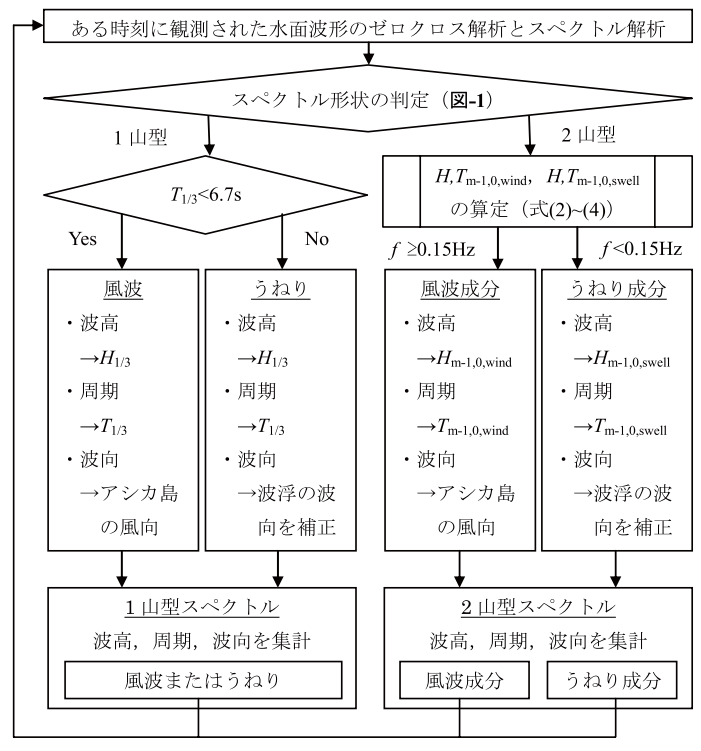

観測期間の全ての時刻で絽り返し，それぞれの出現頻度表を作成 図-3 沖波出現頻度分布の再整理手順 


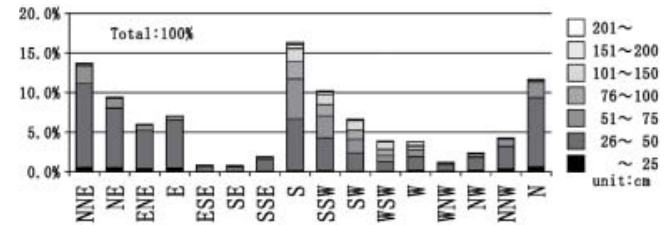

図-4 アシカ島における波向別波高出現頻度分布（現行）

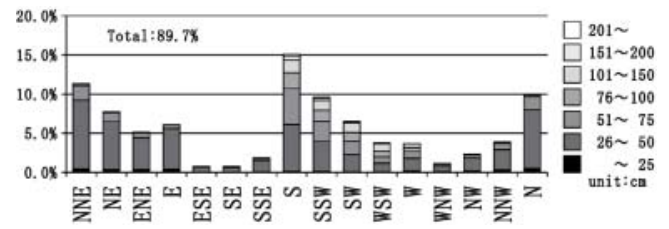

(a) 1 山型スペクトルのみ抽出

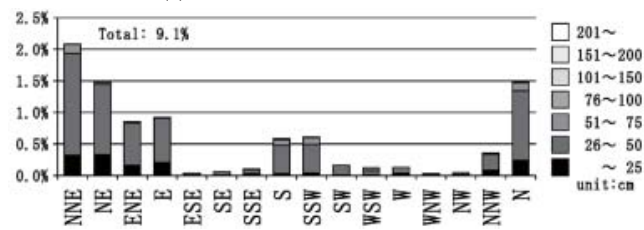

(b) 2 山型スペクトルから分離した風波成分

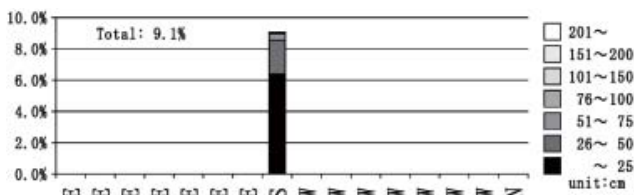

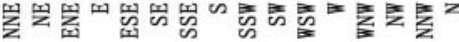

(c) 2 山型スペクトルから分離したうねり成分

図-5 アシカ島に扔ける波向別波高出現頻度分布（再整理）

なわち，うねり成分に対しては $70 \mathrm{~km}$ 沖合の波浮で観測 された波向きをエネルギー平衡方程式法による波浪変形 計算で補正して与え, 風波成分に対してはアシカ島で観 測された風向きと同様として与えた。

ただし，図-1により 2 山型と判定された時刻において， 波浮における波向き，あるいはアシカ島における風向き のいずれか，もしくは両方が不明（欠測または静穏）の ため，風波成分とうねり成分に分離できない場合には， いずれも欠測として取り扱った。このような時刻は 238 データあり，この結果，観測された 2 山型スペクトルを 風波とうねりに分離できた時刻（1731デー夕）は，有意 な水位変動が観測された全時刻のうち，9.1\%であった.

このようにして得られたアシカ島における波向別波高 出現頻度分布を，2山型スペクトルを考慮しない場合と ともに，図-4および図-5に示す，なお，図-5では，先述 したように，2山型と判定されたものの欠測として整理 された時刻が $1.2 \%$ 存在するため, 図-4に比べ，デー夕数 が若干減少している。これらの図より，2山型と判定さ れる波浪は， $\mathrm{S}$ 系のうねりが来襲する台風等による擾乱 時と, $\mathrm{N}$ 系の風波が来襲する冬季風浪時に多く発生し, それぞれ前者が $2 \%$ 程度，後者が $7 \%$ 程度であることがわ かる。 なお，図-5（c）において，25cm未満のうねり波高が 6\%強を占めているのはこのためである，すなわち，冬 季風浪時に観測された 2 山型スペクトルのうち多くで, それほど顕著なうねり成分が観測されなかったと推測さ れる。しかし，2山型スペクトルを分離できなかった 238 データのうち，223データで波浮における波向きが久測 であったことを考慮すると, 久里浜港における実際のう ねり来襲頻度は，さらに $1 \%$ 程度高かった可能性が示唆 される.

一方，2山型スペクトルを分離して得られた， $0.15 \mathrm{~Hz}$ 未満のうねり成分（1731デー夕）の波向きのうち $99 \%$ 以 上は，地形から予想された通り，16方位のうちSから来 襲していることを確認した。なお，残り $1 \%$ の波向きは すべて SSW と推定されたが，それらのうねり波高は最大

表-1 沖波波浪頻度分布に対する代表波浪（計算ケース）

\begin{tabular}{|c|c|c|c|c|c|}
\hline 波高[m] & 周期 [s] & 波向 & $S_{\max }$ & スペクトル & 計算法 \\
\hline \multirow[b]{2}{*}{1} & 4 & \multirow{3}{*}{ E } & 10 & \multirow{15}{*}{$\begin{array}{c}\text { 修正ブレット } \\
\text { シュナイダー } \\
\text { ・光易型スペ } \\
\text { クトル }\end{array}$} & \multirow{2}{*}{ 高山法 } \\
\hline & 5 & & \multirow[b]{2}{*}{25} & & \\
\hline & 6 & & & & $\begin{array}{c}\text { ブシネスク } \\
\text { モデル }\end{array}$ \\
\hline \multirow{3}{*}{1} & 4 & \multirow{4}{*}{ SE } & 10 & & \multirow{2}{*}{ 高山法 } \\
\hline & 5 & & \multirow{3}{*}{25} & & \\
\hline & \multirow[t]{2}{*}{6} & & & & ブシネスク \\
\hline 2 & & & & & \\
\hline 1 & $\frac{4}{5}$ & \multirow{8}{*}{$\mathrm{S}$} & \multirow{8}{*}{25} & & 高山法 \\
\hline 2 & 6 & & & & \multirow{7}{*}{$\begin{array}{c}\text { ブシネスク } \\
\text { モデル }\end{array}$} \\
\hline 1 & 9 & & & & \\
\hline 2 & 9 & & & & \\
\hline 1 & \multirow{2}{*}{12} & & & & \\
\hline 2 & & & & & \\
\hline 1 & \multirow{2}{*}{14} & & & & \\
\hline 2 & & & & & \\
\hline
\end{tabular}

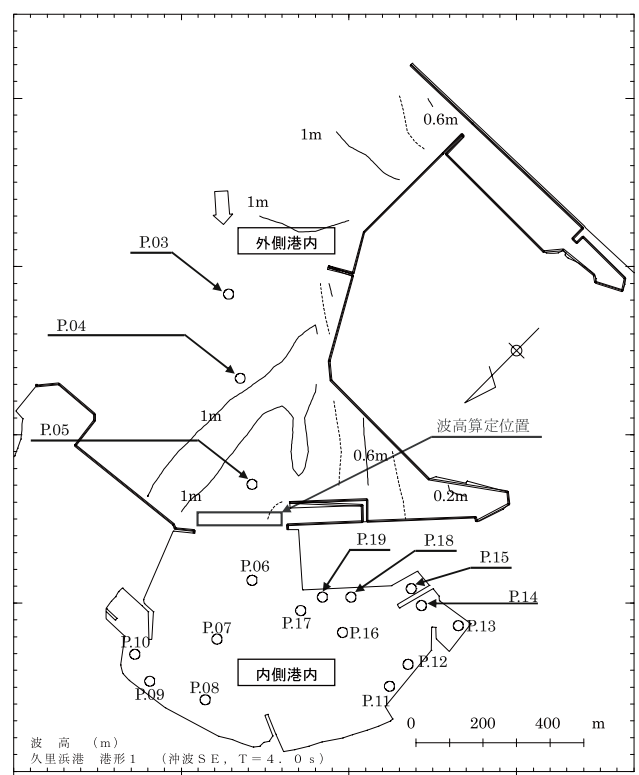

図-6 高山法に対して設定した計算領域 


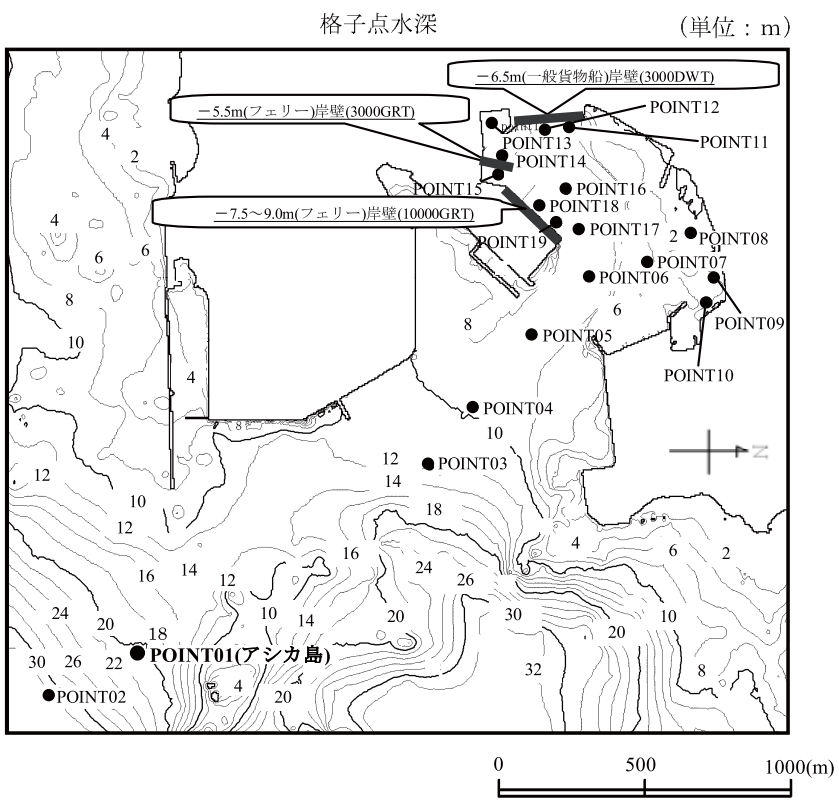

(a) 計算領域（波向 S)

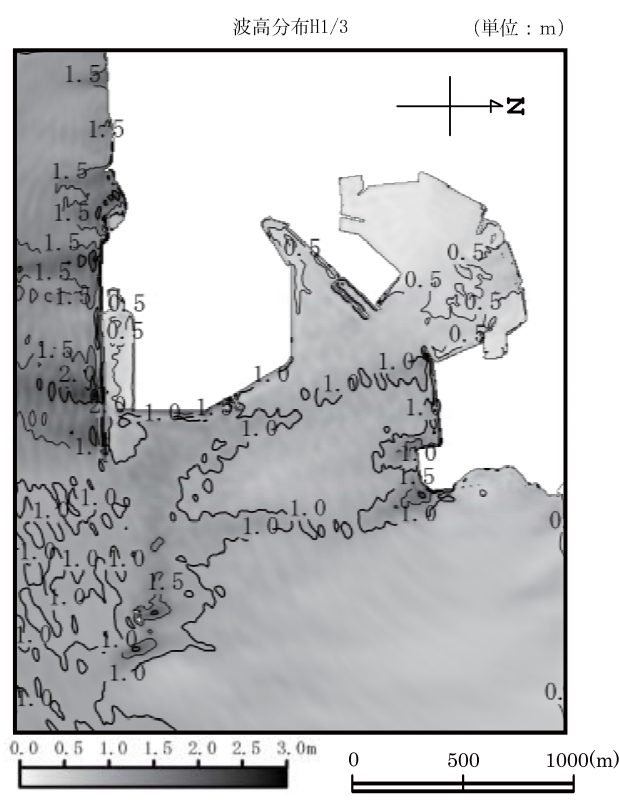

(b) 波高分布（波向 S，波高 $1 \mathrm{~m} ，$ 周期 12s）

図-7 ブシネスクモデルに対して設定した計算領域と計算結果の例

$75 \mathrm{~cm}$ 程度であった。したがって, 以下で行う港内静穏度 解析では，作業の効率化のためこの影響は十分無視でき ると考え，図-5（c）に示したように，うねり成分の波向

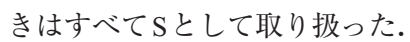

\section{（2）港内静穏度解析のための港内外波浪変形計算}

このようにして得られたアシカ島における沖波波浪出 現頻度分布を代表する波浪諸元を設定し，久里浜港内外 の波浪変形計算を実施した。ここで，代表周期 $6 \mathrm{~s}$ 未満で は港内の屈折・浅水変形が無視できるとして高山法を, 6s 以上では波の非線形性を考慮できるブシネスクモデル を用いた。ささら，ブシネスクモデルによる波浪変形計 算に打いては，高波浪時の砕波による港内波高比分布の 変化も考慮できるよう, 代表波高を2種類設定した。こ れらの計算ケースを表-1に示す。

まず，高山法に対して設定した計算領域を図-6に示す. この計算法では, 港内水深を一定とみなして, 港内の防 波堤や護岸による波の回折や反射の状況を順次計算す る.したがって，これらの波が港奥まで十分到達するよ うに，港内を外側（代表水深 $12 \mathrm{~m}$ ）と内側（代表水深 $8 \mathrm{~m}$ ) に分け, 内側港内の港口部（図の波高算定位置）で両者 を接続している。 また, 外側港内の港口部における波浪 諸元は, 沖のアシカ島位置で設定された代表波浪諸元を, エネルギー平衡方程式法を用いた波浪変形計算により補 正して与えた。なお，図中の番号は，荷役稼働率等を算 定する代表地点を示す。また，コンター線は，外側港内 に対して, 高山法により算定した港内波高分布（波向 SE, 波高 $1 \mathrm{~m}$ ，周期 $4 \mathrm{~s}$ ）を示す.
次に，ブシネスクモデルに対して設定した計算領域お よび計算結果の例を図-7に示す。この計算法では, 水面 波形の伝播過程を時間を追って解き, 港内外で生じる 様々な波浪変形を一度に考慮できる。しかし, 対象とす る波の波長の $1 / 10$ 程度に細かな計算格子を設定する必要 があるため, 特に, 海底地形の影響を受けにくい周期の 短い波に対しては, 高山法を適用するほうが計算精度お よび計算コストの面で有利な場合もある。 また, 格子座 標に対して斜めに進む波ほど計算誤差が大きくなる特性 を有するため, 計算に際しては, 入射波向に応じて地形 を回転させることとした，なお，図中の番号は水面波形 を出力し, 荷役稼働率等を算定する代表地点を示す.

以上のようにして得られた沖波（アシカ島地点）に対 する港内波高比のうち，例えば，波向 $\mathrm{S}$ に対して，p.12， p.15, p.19で代表する各岸壁前面（図-7参照）での算定 結果を，それぞれ図-8（a）～(c) に示す。ここで, 沖波 の波高, 周期による港内波高比の変化は, 平山（2008） にならい，2次曲面で近似できるものと仮定した。図よ り, 各地点ともに, 同じ沖波波高に対しては, 周期が長 いほど波高比が増大する一方, ブシネスクモデルで計算 した 6s 以上の同じ周期に対しては, 波高が大きいほど波 高比が低減することがわかる（高山法では, 周期が同じ であれば, 沖波波高による港内波高比の変化は現れな い). 前者は浅水変形による波高増大や反射率の増大に よる多重反射, 後者は砕波による波高隇衰などの影響が 考えられる.

ただし，高山法を用いて計算した周期 $4,5 \mathrm{~s}$ と, ブシ 


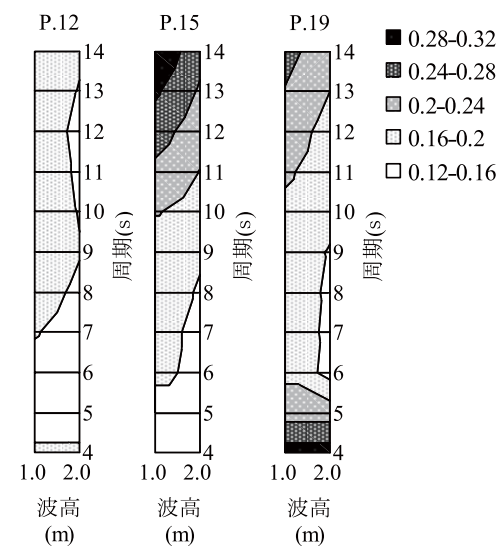

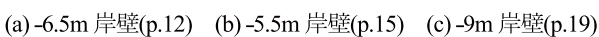

図-8 沖波の波高と周期による港内波高比の変化

表-2 各岸壁における荷役稼働率算定結果の比較

\begin{tabular}{c|c|c|c|c|c|c}
\hline 船型 & \multicolumn{2}{|c|}{$\begin{array}{c}\text { 貨物船 } \\
\text { 3000DWT }\end{array}$} & \multicolumn{2}{c|}{$\begin{array}{c}\text { フェリー } \\
\text { 3000GRT }\end{array}$} & \multicolumn{2}{c}{$\begin{array}{c}\text { フェリー } \\
\text { 10000GRT }\end{array}$} \\
\hline 地点 & P.11 & P.12 & P.14 & P.15 & P.18 & P.19 \\
\hline 現行法 & 99.7 & 99.8 & 100.0 & 99.8 & 100.0 & 99.8 \\
\hline 堤案法 & 99.7 & 99.8 & 100.0 & 99.7 & 100.0 & 99.8 \\
\hline
\end{tabular}

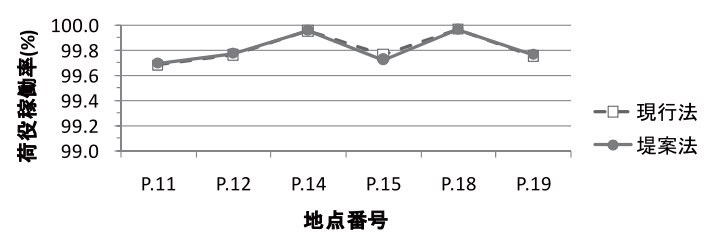

図-9 各岸壁における荷役稼働率算定結果の比

ネスクモデルで計算した周期 $6 \mathrm{~s}$ との間で，周期による港 内波高比の変化が一部逆転している（p.12，p.19）。この 直接的な原因は，異なる計算法による計算特性の違いに あると考えられる．特に高山法では，港外（エネルギー 平衡方程式法), 外側港内, 内側港内へと計算領域を接 続するたびに入射波を与え直すが，このとき，複雑な港 形の港奥に進むほど，成分波の方向分散性に偏りが生じ ることに注意しなければならない。一方，ブシネスクモ デルでは，周期が短くなるほど分散特性の近似精度が劣 り，また差分誤差が大きくなりやすいことに注意が必要 である。したがって，このような場合には，同じ入射条 件に対して波浪変形計算を行い，両者の結果を比較する ことが有効と考えられるが，本研究においては，今後の 課題として留意することとした。

最後に, 各代表地点における波高出現頻度分布は, 図8 等で近似される波高，周期に対する港内波高比に，図4 あるいは図-5に示す沖波波浪出現頻度分布を乗じるこ とにより，それぞれ算定することができる.

\section{（3）荷役稼働率に対する 2 山型スペクトルの影響評価}

荷役稼働率の算定には標準解析法を用い，特に，スペ クトル形状が 2 山型と判定され，かつ風波・うねり成分
の代表諸元が算定された時刻では，それぞれの成分およ びそれらの合成波に対して「稼働」,「不稼働」を判別し， そのすべてで「稼働」と判定された場合のみ，その時刻 に稼働できるものとした。ここで，各対象岸壁における 荷役限界波高は，「港内長周期波影響評価マニュアル」 （財団法人沿岸技術研究センター，平成 16 年 8 月）に従 い, 船種, 船型 (トン数), 相対波向および周期に応じ て設定した。このようにして算定した各岸壁における荷 役稼働率を，2山型スペクトルを考慮しない現行法によ る算定結果と合わせて，表-2および図-9に示す.

表および図より，従来の沖波出現頻度分布に対して2 山型スペクトルを考慮した場合，久里浜港の稼働率に関 しては，港奥のフェリー岸壁で $0.1 \%$ 低下するに留まり， 顕著な影響は確認されなかった。これは，2 山型と判定 された時刻に限ると，本手法により算定される稼働率は $0.5 \%$ 低下するものの，アシ力島の場合，これは全波浪観 測時刻の $9.1 \%$ に過ぎず，さらに，そのうち有意なうねり が来襲していた割合は $2 \%$ 程度であったため，結果的に 僅かな差しか生じなかったものと考えられる。しかし， うねりの来襲頻度が高い外洋に面した港湾などでは, こ のような 2 山型スペクトルが観測された際に，そのうね り周期を過小評価し, 現状の荷役稼働率を実際よりも過 大評価している可能性があるため, 注意が必要である.

\section{4. おわりに}

本研究では, 東京湾に面した久里浜港を対象として, 外洋からのうねりと湾内発生波から成る 2 山型スペクト ルの発生頻度を考慮した港内静榣度解析を行い，通常の 沖波出現頻度分布を用いて算定した荷役稼働率と比較す ることにより，その影響について検討した。

今回の場合, 久里浜港沖の沖波波浪頻度分布において, 波高が比較的大きなうねりの周期を過小評価している割 合は僅か $2 \%$ 程度であったため，港内静穏度に関して顕 著な影響は確認されなかった。しかし，これを考慮する ことにより，港奥のフェリー岸壁で荷役稼働率が $0.1 \%$ 低 下することを確認した。そこで今後は，風波とうねりが 重畳して来襲する頻度の高い港湾とその地形・海象条件 を整理するとともに，それらが港内静穏度に与える影響 の有意性を検証するための事例を蓄積する必要がある.

\section{参 考 文 献}

合田良実（2008）；耐波工学 港湾・海岸構造物の耐波設計, pp.31-32.

財団法人沿岸技術研究センター（2004）；港内長周期波影響 評価マニュアル, p.86

平山克也（2008）；ブシネスクモデルを活用した高精度港内 静穏度解析法の提案, 海岸工学論文集, 第 55 巻, pp.796800 . 